\title{
Bromide and other ions in the snow, firn air, and atmospheric boundary layer at Summit during GSHOX
}

\author{
J. E. Dibb ${ }^{1}$, L. D. Ziemba ${ }^{1, *}$, J. Luxford ${ }^{1}$, and P. Beckman ${ }^{1}$ \\ ${ }^{1}$ Institute for the Study of Earth, Oceans, and Space, University of New Hampshire, Durham, NH, USA \\ *now at: NASA Langley Research Center, Hampton, VA, USA
}

Received: 13 May 2010 - Published in Atmos. Chem. Phys. Discuss.: 31 May 2010

Revised: 6 September 2010 - Accepted: 27 September 2010 - Published: 20 October 2010

\begin{abstract}
Measurements of gas phase soluble bromide in the boundary layer and in firn air, and $\mathrm{Br}^{-}$in aerosol and snow, were made at Summit, Greenland $\left(72.5^{\circ} \mathrm{N}, 38.4^{\circ} \mathrm{W}\right.$, $3200 \mathrm{~m}$ a.s.l.) as part of a larger investigation into the influence of $\mathrm{Br}$ chemistry on $\mathrm{HO}_{\mathrm{x}}$ cycling. The soluble bromide measurements confirm that photochemical activation of $\mathrm{Br}^{-}$in the snow causes release of active $\mathrm{Br}$ to the overlying air despite trace concentrations of $\mathrm{Br}^{-}$in the snow (means 15 and $8 \mathrm{nmol} \mathrm{Br}^{-} \mathrm{kg}^{-1}$ of snow in 2007 and 2008, respectively). Mixing ratios of soluble bromide above the snow were also found to be very small (mean $<1$ ppt both years, with maxima of 3 and 4 ppt in 2007 and 2008, respectively), but these levels clearly oxidize and deposit long-lived gaseous elemental mercury and may perturb $\mathrm{HO}_{\mathrm{x}}$ partitioning. Concentrations of $\mathrm{Br}^{-}$in surface snow tended to increase/decrease in parallel with the specific activities of the aerosol-associated radionuclides ${ }^{7} \mathrm{Be}$ and ${ }^{210} \mathrm{~Pb}$. Earlier work has shown that ventilation of the boundary layer causes simultaneous increases in ${ }^{7} \mathrm{Be}$ and ${ }^{210} \mathrm{~Pb}$ at Summit, suggesting there is a pool of $\mathrm{Br}$ in the free troposphere above Summit in summer time. Speciation and the source of this free tropospheric $\mathrm{Br}^{-}$are not well constrained, but we suggest it may be linked to extensive regions of active $\mathrm{Br}$ chemistry in the Arctic basin which are known to cause ozone and mercury depletion events shortly after polar sunrise. If this hypothesis is correct, it implies persistence of the free troposphere $\mathrm{Br}^{-}$ for several months after peak $\mathrm{Br}$ activation in March/April. Alternatively, there may be a ubiquitous pool of $\mathrm{Br}^{-}$in the free troposphere, sustained by currently unknown sources and processes.
\end{abstract}

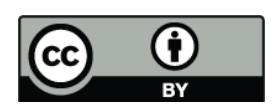

Correspondence to: J. E. Dibb (jack.dibb@unh.edu)

\section{Introduction}

The discovery in 1998 that $\mathrm{NO}_{\mathrm{x}}$ was photochemically produced in snow at Summit, Greenland (Honrath et al., 1999) lead to the realization that sunlit snow is a chemically dynamic environment. Follow up studies have been undertaken at a large number of research sites, in both polar regions and in temperate snowpacks (e.g., Grannas et al., 2007). At Summit it soon became apparent that a large number of very active compounds were produced in the snow pack and released to the overlying air (see the 2002 special issue of Atmospheric Environment on snow photochemical investigations at Summit, volume 36, issues 15-16). Calculations with a photochemical box model indicated that the snow to air fluxes of $\mathrm{H}_{2} \mathrm{O}_{2}, \mathrm{HCHO}$ and $\mathrm{HONO}$ enhanced their mixing ratios significantly and should result in extremely elevated mixing ratios of $\mathrm{HO}_{\mathrm{x}}\left(\mathrm{OH}\right.$ plus $\left.\mathrm{HO}_{2}\right)$ just above the snow at Summit in summer (Yang et al., 2002).

In 2003 and 2004 the first campaigns to include measurements of $\mathrm{OH}$ and $\mathrm{HO}_{2}$ plus $\mathrm{RO}_{2}$, along with all precursors and sinks anticipated to be significant, at Summit were mounted to confirm the predicted enhancements of $\mathrm{HO}_{x}$ and test whether $\mathrm{HO}_{\mathrm{x}}$ cycling and partitioning were consistent with established homogeneous tropospheric chemistry. In the summer 2003 campaign median values of $\mathrm{HO}_{2}$ plus $\mathrm{RO}_{2}$ and $\mathrm{OH}$ around their midday peaks were $4.1 \times 10^{8}$ and $8.4 \times 10^{6}$ molecule $\mathrm{cm}^{-3}$, respectively (Sjostedt et al., 2007). Fully constrained box model calculations predicted similar levels of $\mathrm{HO}_{2}$ plus $\mathrm{RO}_{2}$ (and by extension $\mathrm{HO}_{\mathrm{x}}$ ) but observed $\mathrm{OH}$ exceeded predicted levels by more than a factor of two. Sjostedt et al. (2007) suggested that the good agreement between measured and predicted $\mathrm{HO}_{\mathrm{x}}$ indicated that no large sources or sinks of $\mathrm{HO}_{\mathrm{x}}$ at Summit were being overlooked, but the large underprediction of $\mathrm{OH}$ pointed to poor

Published by Copernicus Publications on behalf of the European Geosciences Union. 
simulation of the cycling between $\mathrm{OH}$ and $\mathrm{HO}_{2}$ in this unique environment. They speculated that active $\mathrm{Br}$ chemistry (not included in the standard model) would push $\mathrm{HO}_{\mathrm{x}}$ partitioning to favor $\mathrm{OH}$, and suggested that as little as $10 \mathrm{ppt}$ of $\mathrm{BrO}$ could largely eliminate the difference between modeled and measured $\mathrm{OH}$ and the $\mathrm{HO}_{2} / \mathrm{OH}$ ratio.

Sjostedt et al. (2007) readily admitted that active $\mathrm{Br}$ chemistry was not expected at Summit, given that the site is $3 \mathrm{~km}$ above sea level and several $100 \mathrm{~km}$ from the coast (assuming that sea salt would be the most likely source of $\mathrm{Br}$ reaching Summit). However, they outlined several lines of indirect evidence that supported the possibility of active $\mathrm{Br}$ chemistry at Summit, and suggested three possible sources: photochemical production in the snow, rapid advection of marine boundary layer air to Summit, and/or downward mixing of free tropospheric air. The GSHOX campaigns in 2007 and 2008 were conducted to confirm whether active $\mathrm{Br}$ chemistry was significant at Summit, and attempt to determine the relative importance of the different potential sources of $\mathrm{Br}$ suggested by Sjostedt et al. (2007). Seven different research groups combined to seek both direct and indirect evidence of $\mathrm{Br}$ chemistry at Summit, as well as measuring reactive gases and meteorological parameters required to model the complex chemical cycling in and above the snow at Summit (see the overview paper by Dibb et al. (2010) for the design of GSHOX and the contributions from all team members). This paper focuses on measurements of soluble ions in the gas phase, associated with aerosol, and in snow made by the University of New Hampshire, with particular attention paid to $\mathrm{Br}^{-}$.

\section{Methods}

\subsection{Sampling location}

All measurements and sample collection for this experiment except DOAS were made at a satellite camp $1.5 \mathrm{~km} \mathrm{SSW} \mathrm{of}$ the center of Summit station in the clean air sector. The active (long-path) DOAS system was installed in a temporary shelter on the south edge of the station, with retroflector arrays located in the clean air sector. The light paths between the DOAS telescope and reflectors were approximately $0.5 \mathrm{~km}$ to the east of the satellite camp. Winds at Summit are not consistently steady in speed or direction, but the least frequent direction is from due north, so all atmospheric sampling has been on the southern, "upwind" side of camp. Hagler et al. (2008) pointed out that, on average, during the summers of 2003 through 2006, winds arriving at the satellite camp location passed through a northern, potentially polluted, sector (defined by point sources of pollution in the camp as well as areas where heavy equipment often was operating), 19\% of the time. These authors recommended use of sector control to interrupt sampling, particularly for experiments that integrated over long periods (days or longer). Our group em- ployed sector control for 2-day filter sampling that targeted organic aerosol, but not for any of the measurements described herein, preferring to filter fast continuous data using clear pollution spikes in NO. However, it may be important to note that in 2007 the sector controller flagged 5.5\% of all sampling time as having wind direction that passed through the potentially camp-influenced sector, compared to $33 \%$ of the 2008 season. It should be noted that the "bad air" sector is defined conservatively, to account for mobile sources that are not always present (e.g., equipment grooming the runway or moving snow). Hagler et al. (2008) observed that during summer 2006 the winds were out of the defined camp sector $21 \%$ of the time, but local pollution (identified by very large enhancements in aerosol absorption monitored continuously) impacted the satellite camp just $7.6 \%$ of the time

\subsection{Soluble gases}

As in several previous experiments at Summit, we used mist chamber samplers to collect soluble gases, which were quantified in near-real-time by ion chromatography (e.g., Dibb et al., 1994, 1998, 2002; Chen et al., 2007; Sjostedt et al., 2007). In all previous campaigns samples were collected manually and then immediately analyzed in a nearby laboratory, for this study we deployed an automated two-channel mist chamber/ion chromatography (MC/IC) system developed for use on ship cruises (Dibb et al., 2004a) and urban air quality studies (Stutz et al., 2010a; Ziemba et al., 2010). This system uses syringe pumps to automatically load/unload the samplers and make injections into the ICs that are packaged in the same enclosure. As in previous Summit experiments, each sampler had its own inlet $(3-\mathrm{m}$ long heated $1.25 \mathrm{~cm}$ OD Teflon tubing that was wrapped for insulation and to exclude light and equipped with Zefluor inlet filter to exclude aerosol), and simultaneous samples were collected in the two samplers. For most of the 2007 season one of the inlets was positioned just a few $\mathrm{cm}$ above the snow while the second was $1 \mathrm{~m}$ above the snow, in a largely unsuccessful attempt to measure gradients (e.g., Honrath et al., 2002). In 2008 we used one sampler to monitor ambient air $1 \mathrm{~m}$ above the surface while the second was primarily used to sample firn air (the air filling pore spaces in the snowpack) at approximately $10 \mathrm{~cm}$ depth. In both years the two inlets were placed next to each other $1 \mathrm{~m}$ above the snow for $20 \%$ of sampling time to assess agreement between the two systems.

Samples were collected for integration intervals of 17.5 min. Emptying the samplers, making injections into the ICs, and then refilling the samplers took $2.5 \mathrm{~min}$, thus we collected 3 samples $h^{-1}$. Every 2.5 to 3 days IC eluents and the sampler fill water were replenished, and the IC response was recalibrated using mixed aqueous standards. This routine maintenance resulted in data gaps of $2-3 \mathrm{~h}$, efforts were made to perform maintenance at varied times of day in order to avoid any bias in sampling diurnal variations. 
The MC samplers remove soluble gases from the airstream in a dense mist of fine, ultrapure, water droplets and continually concentrate the collected gases during sampling (Scheuer et al., 2003; Talbot et al., 1990). Resulting aqueous samples can be analyzed by technique of choice, we chose ion chromatography to quantify very low concentrations of several target ions; bromide, nitrite, and nitrate in this study. Soluble nitrate is overwhelmingly contributed by $\mathrm{HNO}_{3}$ in the sampled air (Talbot et al., 1990) and is reported as $\mathrm{HNO}_{3}$. For bromide and nitrite the speciation of the atmospheric molecules collected in the MC is less certain. Lab tests have confirmed that HONO is quantitatively collected (and analyzed as nitrite) but field campaigns indicate positive interference by unknown additional compounds can be significant at times. In Houston, soluble nitrite measured by MC/IC agreed with HONO measured by long-path DOAS except on a few heavily polluted afternoons when a photochemically produced interferant (not identified) contributed to the soluble nitrite signal (Stutz et al., 2010a). At South Pole and Summit if soluble nitrite is assumed to be HONO it cannot be reconciled with observed $\mathrm{NO}$ and $\mathrm{OH}$ and established chemistry (Chen et al., 2004, 2007; Liao et al., 2006). Pernitric acid may contribute to the nitrite captured in $\mathrm{MC}$ samplers in polar regions, but poor correlation between $\mathrm{HO}_{2} \mathrm{NO}_{2}$ and soluble nitrite was observed at South Pole (Dibb et al., 2004b). At Summit the soluble nitrite is clearly photochemically produced in the snow pack and plays an important part in cycling of nitrogen oxides (Dibb et al., 2002; Honrath et al., 2002) so we continue to measure and report it despite uncertainty of speciation. Our first observations of bromide in MC samples were made from the NCAR C-130 during TOPSE where it was strongly anticorrelated with $\mathrm{O}_{3}$ in the boundary layer over the Arctic sea ice (Evans et al., 2003; Ridley et al., 2003) and considered to be similar to "filterable $\mathrm{Br}^{-}$" observed in ODEs at Alert (Barrie et al., 1988). We have quantified bromide in all subsequent Summit campaigns (e.g., Sjostedt et al., 2007) and in MC/IC samples collected from the NASA DC-8 during the April, 2008 ARCTAS deployment (Neuman et al., 2010). We had speculated that gas phase soluble bromide was dominantly $\mathrm{HBr}$ plus $\mathrm{HOBr}$ but laboratory tests after ARCTAS indicate $\sim 50 \%$ of $\mathrm{Br}_{2}, \mathrm{HOBr}$, and $\mathrm{BrO}$ (presented as pure $\mathrm{Br}_{2}$, and variable mixtures of $\mathrm{Br}_{2}$ plus $\mathrm{HOBr}$ and $\mathrm{Br}_{2}$ plus $\mathrm{BrO}$ ) are captured by the MC and measured as bromide by IC (Liao et al., 2010a). Testing with a pure $\mathrm{HBr}$ source, and mixtures of $\mathrm{HBr}$ with the other $\mathrm{Br}$ gases, is planned. The soluble bromide measured by MC/IC therefore provides a lower limit constraint on the abundance of reactive $\mathrm{Br}$ (sum of $\mathrm{BrO}, \mathrm{Br}_{2}$, $\mathrm{HOBr}$ and $\mathrm{HBr}$ ) in the sampled air.

\subsection{Aerosol}

Aerosol samples were collected onto $90 \mathrm{~mm}$ diameter 2 micron Zefluor filters. The open face filter holders were suspended $1.5 \mathrm{~m}$ above the snow from an aluminum pole.
Each filter was exposed for nominally $24 \mathrm{~h}$, starting at 10:00 WGDT. Sample flow rates were essentially constant at 62 standard liters $\mathrm{min}^{-1}$, yielding sample volumes near 90 standard $\mathrm{m}^{3}$. Blank filters were taken every third day by loading a filter into the holder, mounting it on the pole and then removing it with no air flow. Filters (samples and blanks) were stored frozen for up to 9 days (accumulated until there were 12), and were then extracted and analyzed for major anions and cations by IC in the field. Extraction entailed wetting each filter with $0.5 \mathrm{ml}$ of HPLC grade methanol then shaking and soaking in $20 \mathrm{ml}$ of ultrapure (MilliQ) water, as described by Dibb et al. (2003).

\subsection{Snow}

Surface snow was sampled daily in 2007 (just after the aerosol filter changes) and twice daily $(\sim 10: 00$ and 22:00 local time) in 2008. Following the procedures described by Dibb et al. (2007), three replicates from a known area of the dominant surface layer were transferred into $175 \mathrm{ml}$ precleaned and tared polyethylene bottles, using Lexan scrapers and polyethylene funnels. During intervals with no new snow or drifting the same layer was sampled repeatedly until an event created a new dominant layer. In general, a given layer was replaced every few days, but intervals of calm weather allowed tracking aging of some layers for as long as two weeks. Every tenth bottle was a blank, generated by opening a bottle and placing it next to a sample bottle while the sample was collected. Approximately $20 \mathrm{ml}$ of ultrapure water were subsequently added to each blank. Several shallow pits (at least $50 \mathrm{~cm}$ deep) were sampled at $3 \mathrm{~cm}$ intervals each season. Snow samples were stored frozen until analysis, which was done by IC in the field on the same days that aerosol filter extracts were analyzed.

\section{Results}

\subsection{Soluble gases}

In 2007 the mixing ratio of soluble nitrite approximately $1 \mathrm{~m}$ above the snow consistently varied from minima of $1-3 \mathrm{ppt}$ at night to maxima near $10 \mathrm{ppt}$ shortly after local noon (Fig. 1). The midday peak approached $15 \mathrm{ppt}$ on several days and briefly exceeded $20 \mathrm{ppt}$ on just one day. Soluble bromide also tended to increase and decrease with solar elevation, though the lower mixing ratios overall ( $<1 \mathrm{ppt}$ in most sampling intervals) make the diurnal variations less clear on some days (Fig. 1). Nitric acid frequently exceeded 20 ppt, reaching 105 ppt briefly on 9 June, but intervals of enhanced $\mathrm{HNO}_{3}$ were not always associated with the early afternoon peaks in soluble nitrite (and bromide) (Fig. 1).

During the 2008 campaign soluble nitrite again tended to reach minima very early in the morning $(\sim 1: 00$ local time) but the relatively smooth daytime peaks seen in 2007 were obscured by frequent spikes exceeding $20 \mathrm{ppt}$ (as 

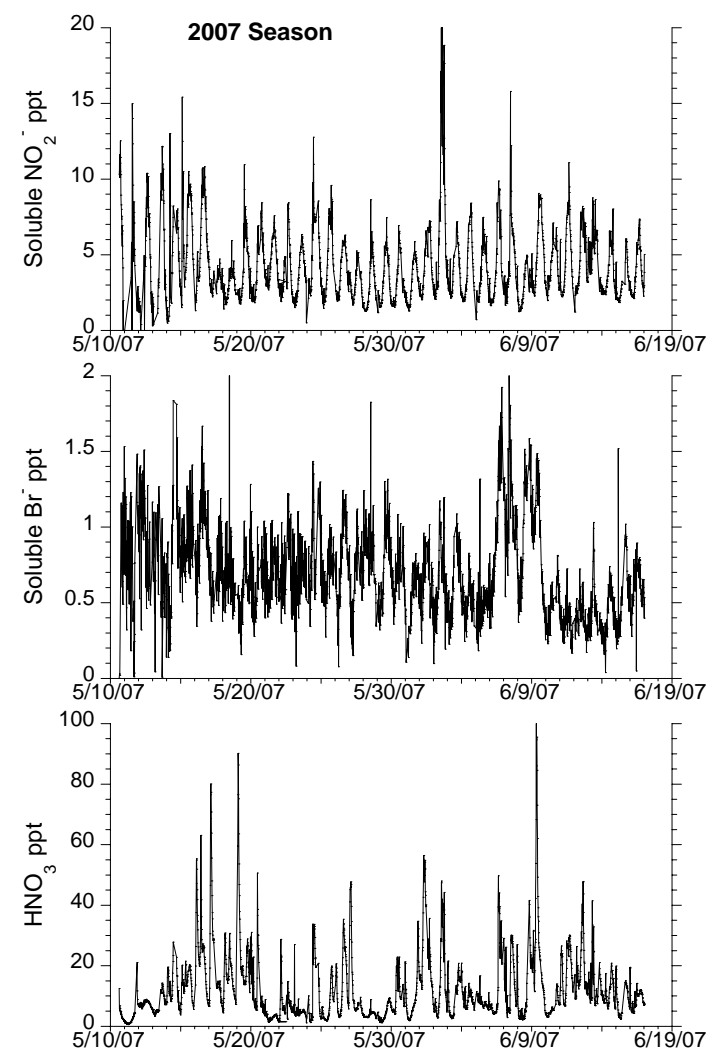

Fig. 1. Mixing ratios of soluble gases from the MC/IC system at Summit in the 2007 season. The inlet was nominally $1 \mathrm{~m}$ above the snow surface (adjusted at least daily in response to drifting), sampling rate was three samples per hour.

high as $80 \mathrm{ppt}$ ) (Fig. 2). For several days early in the season (9-14 June) soluble nitrite mixing ratios remained $>5$ ppt even through the night (Fig. 2), again unlike 2007 (Fig. 1). Nitric acid mixing ratios were also enhanced in early June 2008, compared both to 2007 and to most of the 2008 season (after 18 June) (Figs. 1 and 2). In contrast, soluble bromide mixing ratios tended to be lower throughout the 2008 season (Fig. 2) compared to 2007 (Fig. 1). The numerous spikes in soluble nitrite during 2008 are a reflection of the more frequent advection of camp pollution to the satellite camp in that season. Nitric acid is rarely enhanced in camp plumes, perhaps reflecting too little time to convert emitted NO to $\mathrm{NO}_{2}$ and then produce $\mathrm{HNO}_{3}$ during the $1.5 \mathrm{~km}$ of plume transport from the generator or diesel-powered heavy equipment to the sampling site. It is important to note that soluble bromide shows no apparent enhancements in sampling intervals impacted by camp pollution (reflected as soluble nitrite spikes in Fig. 2).

To assess whether the 2007 and 2008 seasons were representative of conditions at Summit in spring and summer, $\mathrm{MC} / \mathrm{IC}$ results are summarized for the two campaigns in Table 1. We have published $\mathrm{HNO}_{3}$ observations for six Summit campaigns in 1993-1995, and 1998-2000 with mean mixing

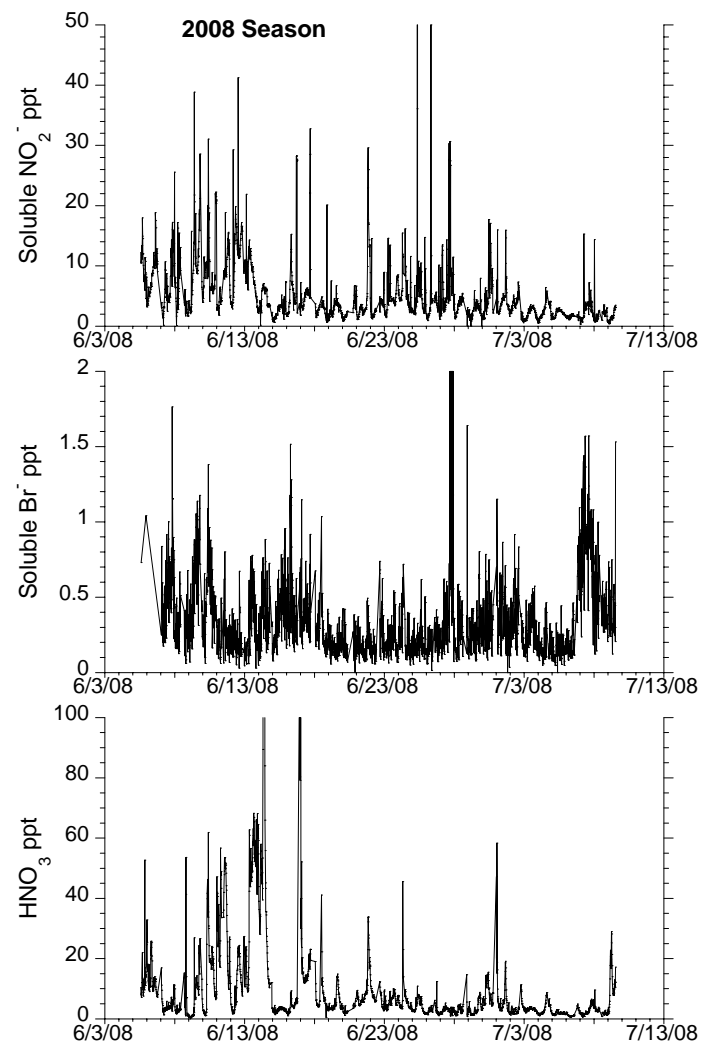

Fig. 2. As in Fig. 1, but for the 2008 season. Note the scale change for soluble nitrite.

ratios ranging from 10-45 ppt (Dibb et al., 1998; Grannas et al., 2007). If the 1998 season is excluded the range is just 10-20 ppt, which suggests that our 2007 and 2008 campaigns encountered the low end of normal $\mathrm{HNO}_{3}$ mixing ratios, with means of 12 and $10 \mathrm{ppt}$, respectively. Similarly, mean mixing ratios of soluble nitrite in 2007 and 2008 (Table 1) were lower than the mean of $13 \mathrm{ppt}$ in 1999 by as much as a factor of three but more similar to means of 7 and $11 \mathrm{ppt}$ in 2000 and 2003, respectively (Yang et al., 2002; Chen et al., 2007). We are not aware of any published summaries of soluble bromide on the Greenland ice sheet, but the 2007 and 2008 ranges and means are comparable to our own unpublished results from 2003 and 2004. Sjostedt et al. (2007) noted that for most of 2003 soluble bromide mixing ratios ranged 1-2 ppt, though our reliance on manual sampling limited the number of data points collected between $\sim$ 1:00 and 8:00 local time. More nighttime sampling in 2003 may have documented more intervals with mixing ratios $<1 \mathrm{ppt}$ if the nighttime minima in 2007 (Fig. 1) are representative, but it is likely that 2008 would still be the season with lowest soluble bromide observed at Summit to date. 
Table 1. Statistical summary of the ambient mixing ratios (ppt) measured by MC/IC above the snow at Summit.

\begin{tabular}{llll}
\hline & $\begin{array}{l}\text { Soluble } \\
\text { Nitrite }\end{array}$ & $\begin{array}{l}\text { Soluble } \\
\text { Bromide }\end{array}$ & $\begin{array}{l}\text { Nitric } \\
\text { Acid }\end{array}$ \\
\hline \multicolumn{4}{c}{ 2007 Season 10 May to 17 June } \\
\hline Mean (sdev) & $4.3(2.4)$ & $0.7(0.3)$ & $12.4(11.4)$ \\
Median & 3.6 & 0.6 & 8.5 \\
Maximum & 20.9 & 2.7 & 105.1 \\
\hline \multicolumn{4}{c}{2008 Season 5 June to 9 July } \\
\hline Mean (sdev) & $5.1(5.0)$ & $0.3(0.3)$ & $9.7(16.4)$ \\
Median & 3.5 & 0.3 & 4.2 \\
Maximum & 79.5 & 4.1 & 203.8 \\
\hline
\end{tabular}

\subsection{Aerosol}

As expected from previous campaigns on the Greenland ice sheet (e.g., Davidson et al., 1993; Bergin et al., 1995; Dibb and Jaffrezo, 1997) the aerosol is dominated by sulfate, which is only partially neutralized by ammonium (Table 2 ). The mean (median) values of the molar ratio $\mathrm{NH}_{4}^{+} / \mathrm{SO}_{4}^{=}$were 0.8 (0.7) and 1.2 (1.2) in 2007 and 2008, respectively, characteristic of acidic aerosol. All other ions were much less abundant than $\mathrm{SO}_{4}^{=}$and $\mathrm{NH}_{4}^{+}$in both seasons. Smaller mixing ratios of dust tracers $\left(\mathrm{Mg}^{2+}\right.$ and $\left.\mathrm{Ca}^{2+}\right)$ in mid summer (2008) compared to early summer (2007) are consistent with peak dust delivery to Summit in April (Dibb et al., 2007) and may explain the smaller mixing ratios of $\mathrm{NO}_{3}^{-}$in 2008 as well (Jordan et al., 2003). (Excess $\mathrm{SO}_{4}^{=}$compared to $\mathrm{NH}_{4}^{+}$suggests that aerosol $\mathrm{NO}_{3}^{-}$is likely to be associated with coarse aerosol, rather than forming fine $\mathrm{NH}_{4} \mathrm{NO}_{3}$.) On average, $\mathrm{Br}^{-}$ was a trace contributor to the ionic burden in aerosol at Summit (Table 2) but the mean (median) $\mathrm{Br}^{-} / \mathrm{Na}^{+}$ratio was 34 (16) and 9 (8) times larger than the seasalt ratio in 2007 and 2008 , respectively.

\subsection{Snow}

Nitrate is the dominant ion in summertime surface snow at Summit (Dibb et al., 1994, 1998) and this was certainly true in 2007 and 2008 (Table 3). The abundance of $\mathrm{NO}_{3}^{-}$and excess $\mathrm{Cl}^{-}$combine to make the snow quite acidic, with average excess anions (assumed to be balanced by $\mathrm{H}^{+}$) amounting to 3525 and 4730 nequiv $\mathrm{kg}^{-1}$ in 2007 and 2008 , respectively. The molar ratio of $\mathrm{NH}_{4}^{+} / \mathrm{SO}_{4}^{=}$also indicates that the snow was more acidic than the aerosol, with mean (median) values of $0.8(0.2)$ and $0.5(0.5)$ in 2007 and 2008. As noted for the aerosol, the concentrations of dust tracers in surface snow were nearly a factor of three lower in 2008 than 2007, reflecting strong seasonality in transport of dust to Summit (more generally, transport of Asian dust throughout the Northern Hemisphere, Dibb et al., 2007).
Overall, the composition of the snow during this experiment was as expected. Anions reflect the dominance of gaseous acids $\left(\mathrm{HNO}_{3}\right.$ and $\left.\mathrm{HCl}\right)$ and partially neutralized accumulation mode $\mathrm{SO}_{4}^{=}$aerosols as summer time sources of ions in snow at Summit. Sources of cations other than $\mathrm{NH}_{4}^{+}$ are much weaker in mid summer and appear to be dominated by long-range transport of dust and episodic advection of biomass burning plumes over Summit. Dibb et al. (2007) presented results of three years of daily sampling at Summit for the major ions (not including $\mathrm{NO}_{2}^{-}$and $\mathrm{Br}^{-}$) and discussed seasonality of their transport and sources. In all cases except for $\mathrm{C}_{2} \mathrm{O}_{4}^{=}$the 2007 and 2008 means and medians (Table 3) are near the midrange of monthly values for May, June, and July observed in that study. Oxalate concentrations in both years of the present study were roughly threefold lower than those in the lowest month of the prior study (May, 2002) and nearly an order of magnitude smaller than in June/July 2001, suggesting smaller influence from boreal wild fires than in several recent years.

We are not aware of prior measurements of $\mathrm{NO}_{2}^{-}$and $\mathrm{Br}^{-}$ in Greenland snow that would provide context for the 2007 and 2008 results. It should be noted that $\mathrm{NO}_{2}^{-}$concentrations in snow were lower in 2008 than 2007 (Table 3) despite the higher mean, and frequent spikes, in gas phase soluble $\mathrm{NO}_{2}^{-}$(Table 1, Fig. 2), suggesting that camp pollution plumes were depositing little $\mathrm{NO}_{2}^{-}$to the snow so close to the source (or that it was not retained in the snow). In contrast, $\mathrm{Br}^{-}$in both the gas phase and the snow was about a factor of two lower in 2008 than 2007 (Tables 1 and 3). The mean (median) $\mathrm{Br}^{-} / \mathrm{Na}^{+}$ratio in surface snow was 113 (33) and 79 (47) times the sea salt ratio in 2007 and 2008, respectively, indicating even more enrichment of $\mathrm{Br}^{-}$in the snow than in the aerosol. Snowpits suggest that $\mathrm{Br}^{-}$is enriched compared to seasalt nearly all year, with the $\mathrm{Br}^{-} / \mathrm{Na}^{+}$ratio only approaching 0.0018 (sea salt value) during winter peaks in $\mathrm{Na}^{+}$(not shown). Similar enhancements of this ratio have been suggested as evidence of active Br chemistry in the Arctic basin (e.g., Toom-Sauntry and Barrie, 2002; Simpson et al., 2005).

\section{Discussion}

\subsection{Implications of gas phase observations}

The time series of soluble gases measured by MC/IC in 2007 hinted that soluble nitrite and bromide tracked solar elevation on most days, with a less obvious diurnal variation in $\mathrm{HNO}_{3}$ (Fig. 1). This early afternoon peak is quite clear in the hourly average mixing ratios of soluble nitrite over the entire 2007 campaign (Fig. 3, recall that local noon is at 14:00 GMT). Soluble $\mathrm{Br}^{-}$and $\mathrm{HNO}_{3}$ also showed daytime peaks in 2007, albeit less pronounced and broader than that of soluble nitrite (Fig. 3). Mixing ratios of $\mathrm{BrO}$ measured by both long path DOAS and CIMS in 2007 tended 
Table 2. Statistical summary of the mixing ratios (ppt) of ions measured in aqueous extracts of $24 \mathrm{~h}$ bulk filter samples.

\begin{tabular}{lrcccccccccc}
\hline & $\mathrm{Na}^{+}$ & $\mathrm{NH}_{4}^{+}$ & $\mathrm{K}^{+}$ & $\mathrm{Mg}^{2+}$ & $\mathrm{Ca}^{2+}$ & $\mathrm{Cl}^{-}$ & $\mathrm{NO}_{2}^{-}$ & $\mathrm{Br}^{-}$ & $\mathrm{NO}_{3}^{-}$ & $\mathrm{SO}_{4}^{=}$ & $\mathrm{C}_{2} \mathrm{O}_{4}^{=}$ \\
\hline Mean & 9.4 & 63.7 & 3.7 & 4.1 & 16.2 & 3.2 & bdl & 0.3 & 11.2 & 77.8 & 1.8 \\
sdev & 10.8 & 38.0 & 3.0 & 5.2 & 18.8 & 4.4 & 0.1 & 0.2 & 12.3 & 40.7 & 0.9 \\
Median & 5.4 & 50.0 & 2.5 & 1.8 & 6.0 & 2.1 & bdl & 0.3 & 7.3 & 63.7 & 1.7 \\
\hline \multicolumn{10}{c}{ 2008 Season } \\
\hline Mean & 11.8 & 44.7 & 3.6 & 1.2 & 6.1 & 5.8 & 0.7 & 0.2 & 3.1 & 54.8 & 1.7 \\
sdev & 4.4 & 25.0 & 1.7 & 0.4 & 2.9 & 4.4 & 0.4 & 0.1 & 3.2 & 47.5 & 1.0 \\
Median & 11.3 & 41.6 & 3.7 & 1.2 & 5.4 & 4.7 & 0.6 & 0.2 & 1.6 & 30.3 & 1.6 \\
\hline
\end{tabular}

Table 3. Statistical summary of the concentrations $\left(\mathrm{nmol} \mathrm{kg}^{-1}\right)$ of ions measured in daily (2007) or twice daily (2008) samples of surface snow at Summit.

\begin{tabular}{|c|c|c|c|c|c|c|c|c|c|c|c|}
\hline & $\mathrm{Na}^{+}$ & $\mathrm{NH}_{4}^{+}$ & $\mathrm{K}^{+}$ & $\mathrm{Mg}^{2+}$ & $\mathrm{Ca}^{2+}$ & $\mathrm{Cl}^{-}$ & $\mathrm{NO}_{2}^{-}$ & $\mathrm{Br}^{-}$ & $\mathrm{NO}_{3}^{-}$ & $\mathrm{SO}_{4}^{=}$ & $\mathrm{C}_{2} \mathrm{O}_{4}=$ \\
\hline \multicolumn{12}{|c|}{2007 Season } \\
\hline Mean & 175.9 & 528.6 & 65.5 & 65.3 & 485.8 & 641.2 & 14.1 & 15.3 & 3143.2 & 745.8 & 17.9 \\
\hline sdev & 134.3 & 756.3 & 73.5 & 56.8 & 314.6 & 370.0 & 8.0 & 9.8 & 1492.3 & 324.4 & 10.9 \\
\hline Median & 146.5 & 215.9 & 30.1 & 43.5 & 376.6 & 526.3 & 12.7 & 14.2 & 2722.2 & 735.1 & 13.6 \\
\hline \multicolumn{12}{|c|}{2008 Season } \\
\hline Mean & 115.9 & 281.6 & 74.0 & 23.1 & 143.7 & 547.0 & 3.7 & 7.7 & 3855.5 & 561.3 & 13.8 \\
\hline sdev & 96.4 & 300.9 & 49.8 & 19.0 & 222.0 & 362.8 & 3.0 & 3.0 & 3090.5 & 487.4 & 15.3 \\
\hline Median & 86.1 & 200.1 & 66.1 & 16.1 & 88.1 & 533.7 & 2.5 & 7.8 & 3330.0 & 417.0 & 9.0 \\
\hline
\end{tabular}

to peak near midday and approach detection limits at night (Stutz et al., 2010b; Liao et al., 2010b). Rapidly depositing reactive gaseous mercury (RGM) also had a pronounced diurnal variation for most of the 2007 season, tracking $j \mathrm{Br}_{2}$ quite closely (Brooks et al., 2010). The magnitude of daytime peaks in RGM increased on days when $\mathrm{BrO}$ was more abundant. The diurnal variations of all three gases measured by MC/IC in 2008 were more complicated, with maxima in the two nitrogen oxides not so clearly linked to solar intensity and a reduced range of diurnal variation in soluble bromide at lower mean mixing ratios (Fig. 3). The mixing ratios of $\mathrm{BrO}$ were likewise smaller, and diurnal variations less consistent, in 2008 (Stutz et al., 2010b; Liao et al., 2010b; Dibb et al., 2010). Also, RGM was rarely enhanced during the daytime in 2008, but it was observed to increase near midnight when surface air temperatures dropped below $-15^{\circ} \mathrm{C}$ (Brooks et al., 2010). A secondary peak in $\mathrm{HNO}_{3}$ in the middle of the night (22:00-2:00 local time) was observed both seasons (Fig. 3). We have not observed nighttime enhancement of $\mathrm{HNO}_{3}$ in previous campaigns, most likely due to limited sampling through the night in all prior experiments which relied on manual sample collection.
Previous studies have established that the dominant source of soluble nitrite above sunlit snow is photochemical production within the surface layer of the snowpack and subsequent flux into the atmosphere (Dibb et al., 2002; Honrath et al. 2002). Most of the $\mathrm{HNO}_{3}$ measured above sunlit snow on the polar ice sheets is formed just above the snow by the $\mathrm{NO}_{2}+\mathrm{OH}$ reaction, with photochemical production of $\mathrm{NO}_{\mathrm{x}}$ and $\mathrm{OH}$ precursors in the snowpack supporting enhanced mixing ratios of $\mathrm{NO}_{2}$ and $\mathrm{OH}$ just above the snow (Dibb et al., 2004b; Chen et al., 2004; Huey et al. 2004). The nighttime enhancements of $\mathrm{HNO}_{3}$ in 2007 and 2008 likely reflect the importance of $\mathrm{NO}_{3}$ and $\mathrm{N}_{2} \mathrm{O}_{5}$ reactions just above the snow (Brown et al., 2004; Dibb et al., 2004a) since the abundances of $\mathrm{NO}_{\mathrm{x}}$ and $\mathrm{OH}$ decrease markedly when the sun approaches the horizon (Dibb et al., 2002; Sjostedt et al., 2007).

The inference that soluble nitrite is produced in the snow pack and then fluxes out, while $\mathrm{HNO}_{3}$ is produced above the snow surface from precursors that flux upward out of the snow, is based on firn air measurements which consistently show large enhancements of soluble nitrite and depletions of $\mathrm{HNO}_{3}$ compared to ambient air just above the snow (Dibb et al., 2002, 2004b). (Snow photochemistry may very well be 


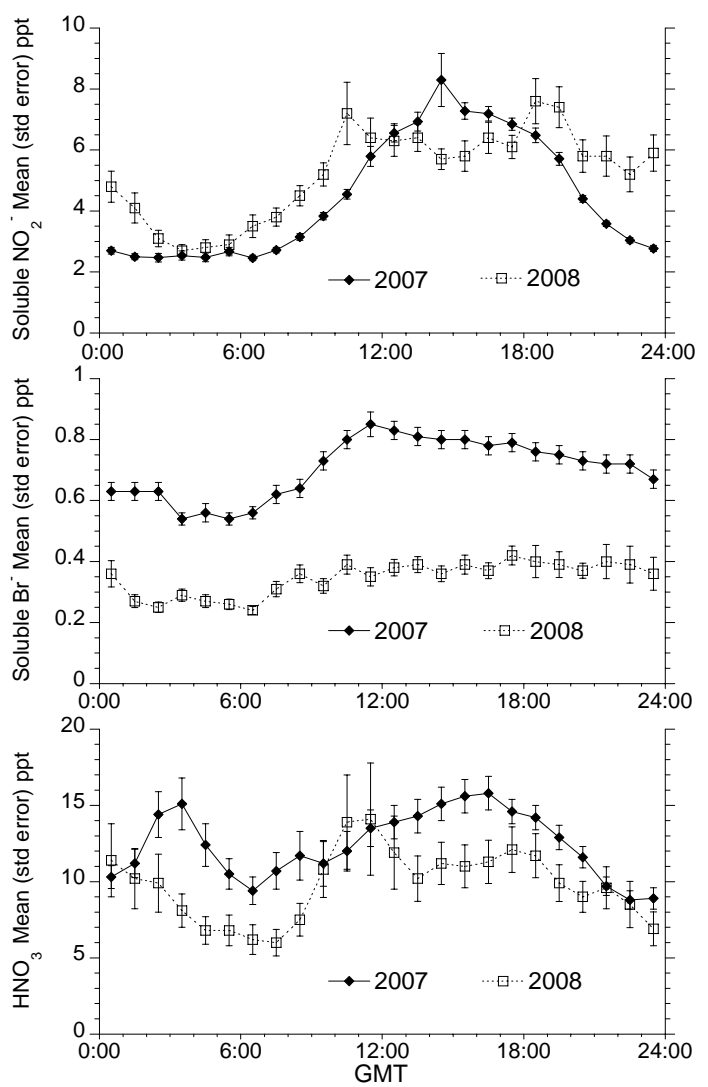

Fig. 3. Mean mixing ratios of soluble nitrite, soluble bromide, and nitric acid in hourly bins for the duration of the 2007 and 2008 campaigns at Summit. Error bars depict the standard error of the mean in each bin. Local Summit time (WGDT) is two hours behind GMT, thus solar noon is $\sim 14: 20 \mathrm{GMT}$.

producing $\mathrm{HNO}_{3}$ in firn air, but it appears to rapidly adsorb to the ice crystals.) To assess whether daytime peaks of soluble bromide were due to production in, and release from, the snow pack, we sampled firn air at a depth of $10 \mathrm{~cm}$ on two days in 2007 and in the $10-15 \mathrm{~cm}$ depth range on 22 of the 32 sampling days in 2008. On both days of firn air sampling in 2007, soluble bromide peaked just after 14:00 GMT in both ambient and firn air, with peak mixing ratios in the firn air more than two times higher than those in the air just above the snow ( 2.5 vs. $1.1 \mathrm{ppt}$ on 26 May and 1.5 vs. $0.7 \mathrm{ppt}$ on 15 June). At night the mixing ratios were similar in and above the snowpack. Similar diurnal patterns in enhancement of soluble bromide were observed on most of the days of firn air sampling in 2008, as reflected in hourly averages calculated for all such days (Fig. 4).

It should be noted that sampling firn air through a probe inserted into the snow pack is prone to significant dilution of the firn air by ambient air rapidly drawn downward to the probe inlet through the highly permeable snowpack (Albert et al., 2002). This effect is more pronounced at shallower depths, and at higher sampling flow rates (like those used

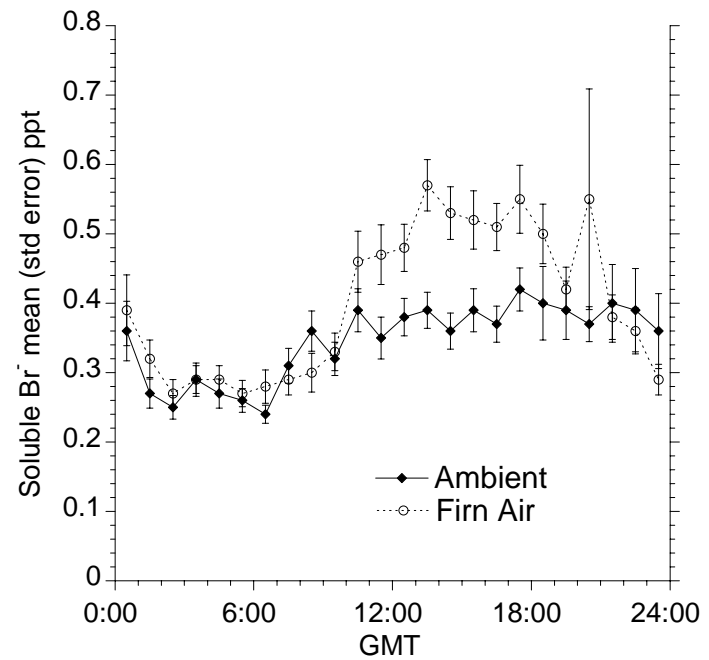

Fig. 4. Comparison of the hourly mean mixing ratios of soluble bromide measured $1 \mathrm{~m}$ above (filled diamonds) and $10-15 \mathrm{~cm}$ below (open circles) the snow surface during 2008. Error bars depict the standard error of the mean in each bin. Simultaneous ambient and firn air measurements were made on 22 of the 32 sampling days.

here for the MC/IC). As a result, the observed mixing ratios of soluble bromide in shallow firn air are decidedly lower limits, but it is clear that soluble bromide is generally enhanced in firn air compared to ambient air near midday at Summit. Thus, as for soluble nitrite, it appears that soluble bromide is produced in the snowpack by photochemically mediated processes and fluxes upward into the overlying near-surface atmosphere. This hypothesis is central to the one dimensional modeling effort, coupling photochemistry in the upper level of the snowpack to that in the atmospheric boundary layer, described by Thomas et al. (2010).

\subsection{Is snow a plausible source of reactive Br at Summit?}

Environments where active $\mathrm{Br}$ chemistry has been shown to play a significant role in tropospheric chemistry include the coastal Arctic and Antarctic boundary layer (including over sea ice), on the shores of saline lakes or salt pans, some parts of the marine boundary layer, and select volcanic plumes (von Glasow and Crutzen, 2007; Simpson et al., 2007). These all share one key feature, greatly enhanced concentrations of halides compared to those observed in the rest of the troposphere, and available at the surface over most continental regions. Summit would appear to represent nearly the extreme opposite end of the spectrum, with extremely low concentrations of halides in both the aerosol and surface snow (Tables 2 and 3). All of the ions in surface snow at Summit, except possibly $\mathrm{NO}_{3}^{-}$, are present in trace concentrations compared to those in terrestrial fresh water throughout the mid and low latitudes (indeed, compared to most treated drinking water) and $\mathrm{Br}^{-}$is a trace component of the ion loading in Summit snow (Table 3). However, the mixing ratios of 
reactive $\mathrm{Br}(\mathrm{BrO}$ or soluble $\mathrm{Br}$, or even their sum) observed above the snow at Summit rarely exceed a few pptv. If we assume that the atmospheric measurements made just above the snow surface are representative of a well mixed $100 \mathrm{~m}$ deep boundary layer, and compare the abundance of reactive $\mathrm{Br}$ in a unit area column from the snow surface to the top of the boundary layer to the amount of $\mathrm{Br}^{-}$in a unit area of the surface layer of snow, it becomes apparent that there is about an order of magnitude more $\mathrm{Br}^{-}$in the top $0.5 \mathrm{~cm}$ of snow than there is $\mathrm{Br}$ in the hypothetical well-mixed boundary layer above it. Considering that sufficient light to sustain active snow photochemistry penetrates to depths in excess of $10 \mathrm{~cm}$ (Galbavy et al., 2007), it thus appears that activation of a small fraction of the $\mathrm{Br}^{-}$in near surface snow could support the observed abundance, and inferred fluxes, of reactive Br just above the snow. Further, it is most likely that reactive $\mathrm{Br}$ decreases quickly with distance above the snow source (Thomas et al., 2010), such that activation of an even smaller fraction of snow $\mathrm{Br}^{-}$could sustain active $\mathrm{Br}$ chemistry in the lowermost few meters or tens of meters of the atmosphere above Summit. On the other hand, there may be sufficient reactive $\mathrm{Br}$ in the boundary layer that deposition could create detectable changes of $\mathrm{Br}^{-}$concentrations in the surface layer (in contrast to $\mathrm{NO}_{3}^{-}-\mathrm{HNO}_{3}$ where the fraction in snow overwhelmingly dominates the system, Dibb et al., 1998).

\subsection{Source of bromide in the snow?}

Despite the relatively low concentration of $\mathrm{Br}^{-}$in surface snow (Table 1), it was greatly enhanced relative to the sea-salt tracer $\mathrm{Na}^{+}$throughout most of the two campaigns (Fig. 5). No clear and consistent relationship between periods with particularly high $\mathrm{Br}^{-} / \mathrm{Na}^{+}$and the concentration of $\mathrm{Br}^{-}$in snow, nor the mixing ratios of soluble bromide or $\mathrm{BrO}$, were apparent. The sustained high values of $\mathrm{Br}^{-} / \mathrm{Na}^{+}$in late May-early June 2007 (Fig. 5), partially reflect elevated $\mathrm{Br}^{-}$concentrations (Fig. 6), but the correlation was weak over the 2007 season and there was no trend in $\mathrm{Br}^{-} / \mathrm{Na}^{+}$with increasing $\mathrm{Br}^{-}$in 2008. Haman et al. (2010) note that several intervals with enhanced $\mathrm{BrO}$ reported by the CIMS team and soluble $\mathrm{Br}^{-}$from the MC/IC occurred in the day or two after an increase in $\mathrm{Br}^{-}$concentration in the surface snow. However, this also was not true in all cases. Nor were the observed variations in the concentration of $\mathrm{Br}^{-}$in surface snow consistently linked to deposition events (new snow or fog deposition) or drifting of snow during enhanced winds.

In 2007 the first eight days of surface snow sampling was conducted under stable conditions with sunny skies, light winds, and significant fog each night, targeting an aging layer that had blown in on 8 May. Through this period concentrations of $\mathrm{Br}^{-}$more or less steadily decreased, and were below detection limits on 22 May (Fig. 6). Stronger winds caused drifting snow through much of the next three days, accompanied by increasing concentrations of $\mathrm{Br}^{-}$in the loose snow

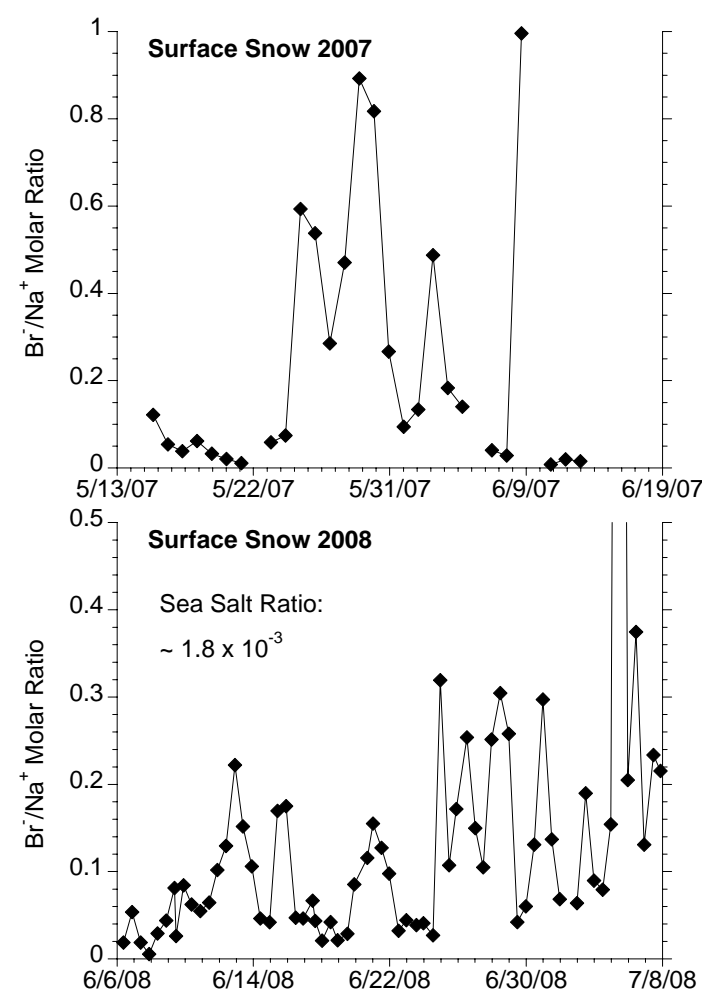

Fig. 5. Ratio of bromide to sodium in surface snow samples. Daily samples in 2007 were collected near 10:00 WGDT, in 2008 samples were collected near 10:00 and 22:00. The ratio in nearly all samples is substantially greater than that in seawater. Note that the scales are not the same in the two panels.

sampled as the surface layer on these days. Concentrations dropped again during several calm days with nighttime fog, followed by another blow with drifting snow and enhanced $\mathrm{Br}^{-} 28$ May through the morning of 1 June (Fig. 6). The first significant snowfall event occurred on 2 June, this layer contained $\sim 20 \mathrm{nmol} \mathrm{Br}^{-} \mathrm{L}^{-1}$, as did additional new snow events sampled on 4 and 5 June. It should be noted that winds were strong enough to cause drifting of the 2 June snowfall, but little change in $\mathrm{Br}^{-}$concentration was seen in the 3 June sample of the drifted new snow. Further, $\mathrm{Br}^{-}$concentrations in new snow events sampled on 6,14 and 15 June were below detection limits, and drifting during 5 of the last 12 days of sampling did not produce enhancements above $7 \mathrm{nmol} \mathrm{Br}^{-} \mathrm{L}^{-1}$ (Fig. 6).

The 2008 sampling season started like 2007 with settled weather and frequent nighttime fog, the first winds strong enough to cause drifting did not occur until the evening of 15 June, and no significant snowfall events were observed until 19 June. Unlike 2007, the settled weather early in 2008 was accompanied by increasing concentrations of $\mathrm{Br}^{-}$in the surface snow, reaching seasonal maximum 14 June before winds increased (Fig. 6). Fresh snow layers sampled 19, 23, 25, 26, 28 and 30 June and 6 and 7 July had $\mathrm{Br}^{-}$concentrations ranging $3-12 \mathrm{nmol} \mathrm{L}^{-1}$. 


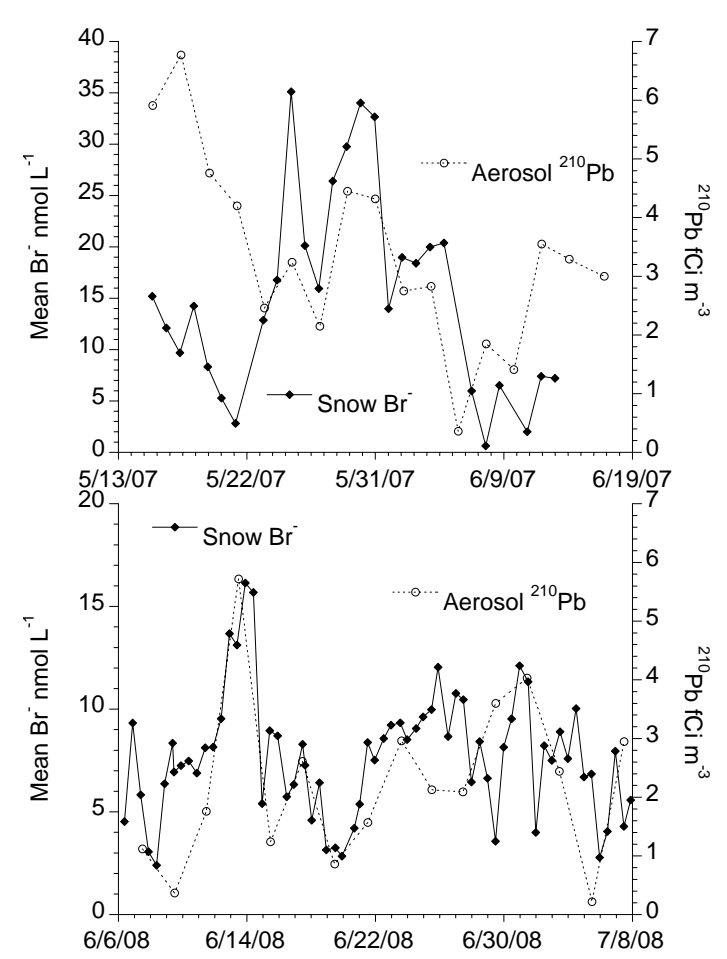

Fig. 6. Time series of bromide concentrations in surface snow compared to the specific activity of ${ }^{210} \mathrm{~Pb}$ in bulk aerosol samples. As noted, snow was sampled daily in 2007 and twice daily in 2008. Filter samples for ${ }^{210} \mathrm{~Pb}$ integrated over two-day intervals.

The positive relationship between $\mathrm{Br}^{-}$concentrations in snow and the specific activity of ${ }^{210} \mathrm{~Pb}$ (Fig. 6) (also ${ }^{7} \mathrm{Be}$, not shown) in aerosol was the most consistent correlation between bromide compounds (in all phases) and any other parameter measured in the two seasons. Collection of 48-h long bulk aerosol samples for quantification of these natural radionuclide tracers is part of the baseline program of the GEOSummit Observatory. Dibb (2007) described the sampling protocol and the implications of covariations in ${ }^{7} \mathrm{Be}$ and ${ }^{210} \mathrm{~Pb}$ observed in the first 5 years of sampling. Briefly, isolation (ventilation) of the boundary layer air above Summit by strong temperature inversions (vertical mixing strong enough to disrupt the inversion) causes aerosol and associated tracers to decrease through fog and dry deposition (increase by replenishment of aerosol). Thus, despite different sources, ${ }^{7} \mathrm{Be}$ and ${ }^{210} \mathrm{~Pb}$ tend to be strongly correlated at Summit, as they were in the 2007 and 2008 seasons (Fig. 7). Increased ${ }^{210} \mathrm{~Pb}$ activity is therefore primarily due to downward mixing of fresh aerosol from the free troposphere to the surface at Summit.

The observation that $\mathrm{Br}^{-}$in snow tends to track variations in ${ }^{210} \mathrm{~Pb}$ suggests that vertical mixing from aloft is likewise the source of $\mathrm{Br}^{-}$reaching the snow surface during summer at Summit. As discussed above, it does not appear that scavenging by snowfall is necessarily required to deliver the $\mathrm{Br}^{-}$ to the surface, but removal by a combination of snow, fog

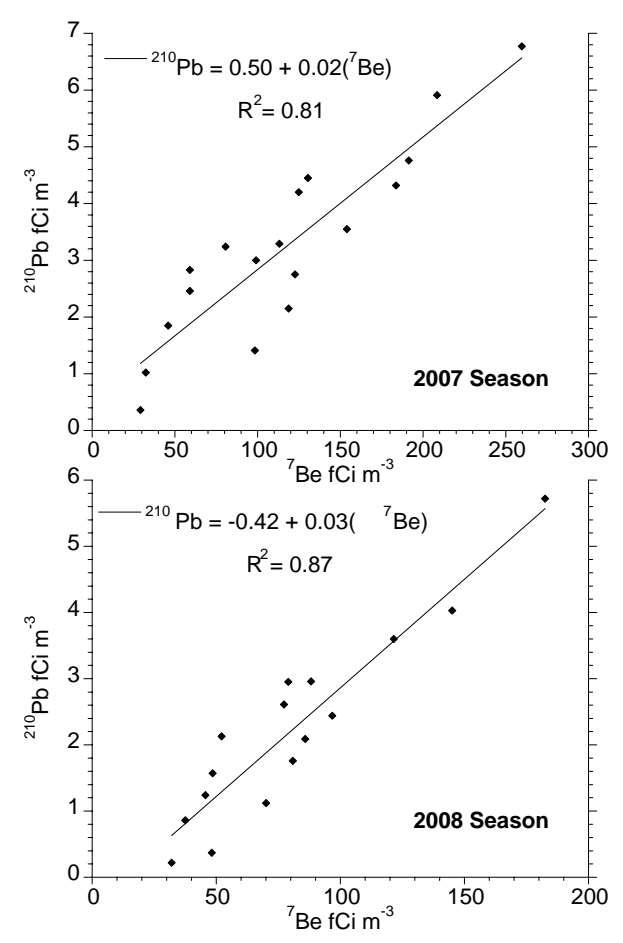

Fig. 7. Scatter plots of ${ }^{210} \mathrm{~Pb}$ vs. ${ }^{7} \mathrm{Be}$ from the bulk aerosol samples collected during the 2007 and 2008 intensive campaigns. Lines are linear least squares regression fits.

and dry deposition must be efficient and rapid since parallel enhancements of gaseous and aerosol-associated $\mathrm{Br}$ compounds in the boundary layer above the snow are not generally seen. Our surface snow sampling protocol allows calculation of the inventory of $\mathrm{Br}^{-}$(or any of the other ions) present per unit area of the surface layer sampled each sampling time (Dibb et al., 1998), with changes in inventory between samples providing insight into net fluxes. Considering observed increases in $\mathrm{Br}^{-}$inventories provides some constraints on the plausibility of the hypothesis that vertical mixing can provide enough $\mathrm{Br}^{-}$to account for the net downward fluxes.

In late May 2007 inferred net deposition of $\mathrm{Br}^{-}$exceeded $19 \mathrm{nmol} \mathrm{m}^{-2} \mathrm{~d}^{-1}$ on 5 days, with the largest change of $41 \mathrm{nmol} \mathrm{m}^{-2}$ seen between 23 and 24 May. Complete removal of $\mathrm{Br}^{-}$from a well mixed atmospheric column $1 \mathrm{~km}$ deep with a mixing ratio of $0.9 \mathrm{ppt}$ would support the inferred maximum depositional flux. Assuming deeper vertical mixing would mean lower mixing ratios in the free troposphere would be viable, or would allow relaxing the assumption of complete removal (e.g., a $5 \mathrm{~km}$ deep column at $0.18 \mathrm{ppt}$ would also contain $41 \mathrm{nmol} \mathrm{of} \mathrm{Br}^{-}$). We note that neither $\mathrm{BrO}$ or soluble $\mathrm{Br}$ were detected between 4 and $8 \mathrm{~km}$ pressure altitude when the NASA DC- 8 spiraled down over Summit on 9 July 2008 (Neumann et al., 2010), however, the detection limit for soluble bromide by MC/IC during the ARCTAS airborne campaign increased from $\sim 1 \mathrm{ppt}$ in the 
boundary layer to $\sim 6 \mathrm{ppt}$ at $12 \mathrm{~km}$. Therefore, it is possible that mixing free tropospheric air down to the surface at Summit could account for even the largest changes of $\mathrm{Br}^{-}$in the snow. All other observed increases in inventory in both seasons imply net fluxes $<10 \mathrm{nmol} \mathrm{m}^{-2} \mathrm{~d}^{-1}$. It should also be noted that the steady decrease in $\mathrm{Br}^{-}$concentration when the same layer of snow was repeatedly sampled early in the 2007 (Fig. 6) season suggests a net flux out of the snow at about $3 \mathrm{nmol} \mathrm{m}^{-2} \mathrm{~d}^{-1}$. Dispersing this into a well mixed $100 \mathrm{~m}$ column below the inversion would yield a mixing ratio of $0.7 \mathrm{ppt}$, comparable to means observed in the air just above the snow (Table 1).

Our observations at the surface at Summit do not provide insight into whether $\mathrm{Br}^{-}$in the free troposphere is present in the gas or aerosol phase. Higher values of the $\mathrm{Br}^{-} / \mathrm{Na}^{+}$ ratio in snow than in the aerosol may indicate contributions from a gas phase source in clouds forming snow, or perhaps the aerosol most enriched in $\mathrm{Br}^{-}$is preferentially taken up by snow. The source of $\mathrm{Br}^{-}$in the free troposphere above Summit is likewise unknown. Contributions from the North Atlantic and/or the Arctic basin would seem likely. The large enhancements of $\mathrm{Br}^{-}$relative to $\mathrm{Na}^{+}$indicate extensive processing of sea salt (if that is the dominant initial source of $\mathrm{Br}^{-}$), leading us to speculate that the well documented active $\mathrm{Br}$ chemistry in the Arctic in springtime may result in a free tropospheric pool of $\mathrm{Br}^{-}$at northern high latitudes. Airborne observations during ARCTAS and ARCPAC in April 2008 did suggest significant venting of BrO from the marine boundary layer into the free troposphere in association with some extreme ozone depletion events (Salawitch et al., 2010). Less abundant $\mathrm{Br}^{-}$in aerosol and snow at Summit in June-July (2008) than May-June (2007) may be consistent with a springtime Arctic source of $\mathrm{Br}^{-}$getting transported to Summit. Lower concentrations of $\mathrm{Br}^{-}$in the snow during mid-summer than early summer would then result in lower mixing ratios of soluble bromide and $\mathrm{BrO}$ just above the snow, as observed (Thomas et al., 2010). However, non-methane hydrocarbon ratios from year-round sampling provide weak or no evidence of $\mathrm{Br}$ chemistry at Summit in March-April when ODE's are common, and $\mathrm{Br}$ chemistry is most active, in the Arctic basin (Gorham et al., 2010). Perhaps the strongly stable Arctic atmosphere prevents lofting of $\mathrm{Br}^{-}$into the free troposphere until later in the year (e.g., Scheuer et al., 2003).

\section{Conclusions}

Measurements of gas phase soluble bromide in the air just above, and in the pore spaces of, snow at Summit, Greenland confirm that active $\mathrm{Br}$ chemistry is occurring at this site, despite extremely small abundance of $\mathrm{Br}^{-}$(indeed, all halides) in the snow at the crest of the Greenland ice sheet. Despite the trace levels of $\mathrm{Br}^{-}$in snow, the $\mathrm{Br}^{-} / \mathrm{Na}^{+}$ratio is greatly in excess of the seasalt ratio throughout the sum- mer. Higher mixing ratios of soluble bromide in firn air than the atmosphere, and the tendency for peak mixing ratios to occur near local noon, indicate that photochemical activation of $\mathrm{Br}^{-}$in the snow sustains active $\mathrm{Br}$ chemical cycling above the snow. Companion papers in this issue demonstrate that $\mathrm{Br}$ chemistry has significant impacts on speciation of $\mathrm{Hg}, \mathrm{HO}_{\mathrm{x}}$ cycling, and NMHC ratios at times, despite mixing ratios of soluble bromide and $\mathrm{BrO}$ rarely exceeding a few ppt. Bromide concentrations in the surface snow often increased when vertical mixing disrupted strong inversions and allowed free tropospheric air to replenish the boundary layer just above the snow. Speciation of the apparent $\mathrm{Br}^{-}$ reservoir in the free troposphere above Summit is uncertain, as is the relative importance of gaseous vs. aerosol-associated compounds. We hypothesize that widespread $\mathrm{Br}^{-}$activation leading to ozone depletion in the Arctic basin shortly after polar sunrise also results in the creation of this free tropospheric $\mathrm{Br}^{-}$pool, which is then not efficiently transported to Summit until early summer. Marine boundary layer processes in the North Atlantic might also be a source of excess $\mathrm{Br}^{-}$in the free troposphere over Greenland, but this would appear difficult to confirm experimentally.

Acknowledgements. We thank the rest of the GSHOX team for their help and encouragement at Summit, and for many discussions of all the findings from this collaborative experiment. Financial support was provided by NSF GEO ATM (now AGS) Tropospheric Chemistry program and logistical support was provided by NSF OPP. Excellent support and service by CPS staff in Kanger and at Summit, and airlift by the NYANG 109th Airwing is greatly appreciated. We are grateful for permission to perform this research at Summit, granted by Greenland Home Rule and the Danish Polar Center.

Edited by: R. von Glasow

\section{References}

Albert, M. R., Grannas, A. M., Bottenheim, J., Shepson, P. B., and Perron, F. E.: Processes and properties of snow-air transfer in the high Arctic with application to interstitial ozone at Alert, Canada, Atmos. Environ., 36, 2779-2787, 2002.

Barrie, L. A., Bottenheim, J. W., Schnell, R. C., Crutzen, P. J., and Rasmussen, R. A.: Ozone destruction and photochemical reactions at polar sunrise in the lower Arctic atmosphere, Nature, 334, 138-141, 1988.

Bergin, M. H., Jaffrezo, J.-L., Davidson, C. I., Dibb, J. E., Pandis, S. N., Hillamo, R., Maenhaut, W., Kuhns, H. D., and Makela, T.: The contributions of snow, fog and dry deposition to the summer fluxes of major anions and cations at Summit, Greenland, J. Geophys. Res., 100, 16275-16288, 1995.

Brooks, S. B., Moore, C., Lew, D., Lefer, B., Huey, L. G., and Tanner, D.: Temperature and sunlight controls of mercury oxidation and deposition atop the Greenland ice sheet, Atmos. Chem. Phys. Discuss., in preparation, 2010.

Brown, S. S., Dibb, J. E., Stark, H., Aldener, M., Vozella, M., Whitlow, S., Williams, E. J., Lerner, B. M., Jakoubek, R., Mid- 
dlebrook, A. M., De Gouw, J. A., Warneke, C., Goldan, P. D., Kuster, W. C., Angevine, W. M., Sueper, D. T., Quinn, P. K., Bates, T. S., Meagher, J. F., Fehsenfeld, F. C., and Ravishankara, A. R.: Nighttime removal of $\mathrm{NO}_{\mathrm{x}}$ in the summer marine boundary layer, Geophys. Res. Lett., 31, L07108, doi:10.1029/2004GL019412, 2004.

Chen, G., Davis, D., Crawford, J., Hutterli, L. M., Huey, L. G., Slusher, D., Mauldin, L., Eisele, F., Tanner, D., Dibb, J., Buhr, M., McConnell, J., Lefer, B., Shetter, R., Blake, D., Song, C. H., Lombardi, K., and Arnoldy, J.: A reassessment of $\mathrm{HO}_{\mathrm{x}}$ South Pole chemistry based on observations recorded during ISCAT 2000, Atmos. Environ., 38, 5451-5461, 2004.

Chen, G., Huey, L. G., Crawford, J. H., Olsen, J. R., Hutterli, M. A., Sjostedt, S., Tanner, D., Dibb, J., Lefer, B., Blake, N., Davis, D., and Stohl, A.: An assessment of the polar $\mathrm{HO}_{\mathrm{x}}$ budget based on 2003 Summit Greenland field observations, Atmos. Environ., 41, 7806-7828, doi:10.1016/j.atmosenv.2007.06.014, 2007.

Davidson, C. I., Jaffrezo, J.-L., Mosher, B. W., Dibb, J. E., Borys, R. D., Bodhaine, B. A., Rasmussen, R. A., Boutron, C. F., Gorlach, U., Cachier, H., Ducret, J., Colin, J.-L., Heidam, N. Z., Kemp, K., and Hillamo, R.: Chemical constituents in the air and snow at Dye 3, Greenland: I, Seasonal variations, Atmos. Environ., 27A, 2709-2722, 1993.

Dibb, J. E.: Vertical mixing above Summit, Greenland: Insights into seasonal and high frequency variability from the radionuclide tracers ${ }^{7} \mathrm{Be}$ and ${ }^{210} \mathrm{~Pb}$, Atmos. Environ., 41, 5020-5030, doi:10.1016/j.atmosenv.2006.12.005, 2007.

Dibb, J. E. and Jaffrezo, J. -L.: Air-snow investigations at Summit: An overview, J. Geophys. Res., 102, 26795-26807, 1997.

Dibb, J. E., Talbot, R. W., and Bergin, M. H.: Soluble acidic species in air and snow at Summit, Greenland, Geophys. Res. Lett., 21, 1627-1630, 1994.

Dibb, J. E., Talbot, R. W., Munger, J. W., Jacob, D. J., and Fan, S.M.: Air-snow exchange of $\mathrm{HNO}_{3}$ and $\mathrm{NO}_{\mathrm{y}}$ at Summit, Greenland, J. Geophys. Res., 103, 3475-3486, 1998.

Dibb, J. E., Arsenault, M., Peterson, M. C., and Honrath, R. E.: Fast nitrogen oxide photochemistry in Summit, Greenland snow, Atmos. Environ., 36, 2501-2511, 2002.

Dibb, J. E., Talbot, R. W., Scheuer, E., Seid, G., Avery, M. A., and Singh, H. B.: Aerosol chemical composition in Asian continental outflow during TRACE-P: Comparison to PEM-West B, J. Geophys. Res., 108, 8815, doi:10.1029/2002JD003111, 2003.

Dibb, J. E., Scheuer, E., Whitlow, S. I., Vozella, M., Williams, E., and Lerner, B.: Ship-based nitric acid measurements in the Gulf of Maine during New England Air Quality Study 2002, J. Geophys. Res., 109, D20303, doi:10.1029/2004JD004843, 2004a.

Dibb, J. E., Huey, L. G., Slusher D. L., and Tanner, D. J.: Soluble reactive nitrogen oxides at South Pole during ISCAT 2000, Atmos. Environ., 38, 5399-5409, 2004b.

Dibb, J. E., Whitlow, S. I., and Arsenault, M.: Seasonal variations in the soluble ion content of snow at Summit, Greenland: Constraints from three years of daily surface snow samples, Atmos. Environ.,41, 5007-5019, doi:10.1016/j.atmosenv.2006.12.010, 2007.

Dibb, J. E., Thomas, J. L., von Glasow, R., Stutz, J., Haman, C., Lefer, B., Liao, J., Huey, L. G., and Brooks, S. B.: GSHOX overview, Atmos. Chem. Phys. Discuss., in preparation, 2010.

Evans, M. J., Jacob, D. J., Atlas, E., Cantrell, C. A., Eisele, F., Flocke, F., Fried, A., Mauldin, R. L., Ridley, B. A., Wert, B.,
Walega, J., Weinheimer, A., Blake, D., Heikes, B., Snow, J., Talbot R., and Dibb, J.: Coupled evolution of $\mathrm{BrO}_{\mathrm{x}}-\mathrm{CLO}_{\mathrm{x}}-\mathrm{HO}_{\mathrm{x}}-$ $\mathrm{NO}_{\mathrm{x}}$ chemistry during bromine-catalyzed ozone depletion events in the arctic boundary layer, J. Geophys. Res., 108(D4), 8368 , doi:10.1029/2002JD002732, 2003.

Galbavy, E. S., Anastasio, C., Lefer, B., and Hall, S.: Light penetration in the snowpack at Summit, Greenland, Part 2 Nitrate photolysis, Atmos. Environ., 41, 5091-5100, 2007.

Gorham, K., Blake, N. J., Wingenter, O., Beyersdorf, A. J., Swanson, A., and Blake, D. R.: Evidence of halogen chemistry at Summit from NMHC ratios, Atmos. Chem. Phys. Discuss., in preparation, 2010.

Grannas, A. M., Jones, A. E., Dibb, J., Ammann, M., Anastasio, C., Beine, H. J., Bergin, M., Bottenheim, J., Boxe, C. S., Carver, G., Chen, G., Crawford, J. H., Domin, F., Frey, M. M., Guzmán, M. I., Heard, D. E., Helmig, D., Hoffmann, M. R., Honrath, R. E., Huey, L. G., Hutterli, M., Jacobi, H. W., Klán, P., Lefer, B., McConnell, J., Plane, J., Sander, R., Savarino, J., Shepson, P. B., Simpson, W. R., Sodeau, J. R., von Glasow, R., Weller, R., Wolff, E. W., and Zhu, T.: An overview of snow photochemistry: evidence, mechanisms and impacts, Atmos. Chem. Phys., 7, 4329-4373, doi:10.5194/acp-7-4329-2007, 2007.

Haman, C., Lefer, B., Dibb, J. E., and Clements, C.: Evidence for a mid- to upper-tropospheric source of bromide reaching Summit, Atmos. Chem. Phys. Discuss., in preparation, 2010.

Hagler, G. S. W., Bergin, M. H., Smith, E. A., Town, M., and Dibb, J. E.: Local anthropogenic impact on particulate elemental carbon concentrations at Summit, Greenland, Atmos. Chem. Phys., 8, 2485-2491, doi:10.5194/acp-8-2485-2008, 2008.

Honrath, R. E., Peterson, M. C., Guo, S., Dibb, J. E., Shepson,P. B., and B.: Campbell, Evidence of $\mathrm{NO}_{\mathrm{x}}$ production within or upon ice particles in the Greenland snowpack, Geophys. Res. Lett., 26, 695-698, 1999.

Honrath, R. E., Peterson, M. C., Lu, Y., Dibb, J. E., Arsenault, M. A., Cullen, N. J., and Steffen, K.: Vertical fluxes of $\mathrm{NO}_{\mathrm{x}}$, HONO, and $\mathrm{HNO}_{3}$ above the snowpack at Summit, Greenland, Atmos. Environ., 36, 2629-2640, 2002.

Huey, L. G., Tanner, D. J., Slusher, D. L., Dibb, J. E., Arimoto, R., Chen, G., Davis, D., Buhr, M. P., Nowak, J. B., Mauldin, R. L., Eisele III, F. L., and Kosciuch, E.: CIMS measurements of $\mathrm{HNO}_{3}$ and $\mathrm{SO}_{2}$ at the South Pole during ISCAT 2000, Atmos. Environ., 38, 5411-5421, 2004.

Jordan, C. E., Dibb, J. E., Anderson, B. E., and Fuelberg, H. E.: Uptake of nitrate and sulfate on dust aerosols during TRACE-P, J. Geophys. Res., 108, 8817, doi:10.1029/2002JD003101, 2003.

Liao, J., Huey, L. G., Tanner, D. J., Dibb, J. E., and Scheuer, E.: Discussion of $\mathrm{Br}$ speciation sampling issues impacting CIMS and MC/IC, Atmos. Chem. Phys. Discuss., in preparation, 2010a.

Liao, J., Huey, L. G., Tanner, D. J., Brooks, S., Dibb, J. E., Stutz, J., Thomas, J., Lefer, B., Haman, C., and Gorham, K.: Observations of hydroxyl and peroxy radicals ant the impact of BrO at Summit, Greenlan in 2007 and 2008, Atmos. Chem. Phys. Discuss., in preparation, $2010 \mathrm{~b}$.

Liao, W., Case, A. T., Mastromarino, J., Tan, D., and Dibb, J. E.: Observations of HONO by laser-induced fluorescence at the South Pole during ANTCI 2003, Geophys. Res. Lett., 33, L09810, doi:10.1029/2005GL025470, 2006.

Neuman, J. A., Nowak, J. B., Huey, L. G., Burkholder, J. B., Dibb, J. E., Holloway, J. S., Liao, J., Peischl, J., Roberts, J. M., Ryer- 
son, T. B., Scheuer, E., Stark, H., Stickel, R. E., Tanner, D. J., and Weinheimer, A.: Bromine measurements in ozone depleted air over the Arctic Ocean, Atmos. Chem. Phys., 10, 6503-6514, doi:10.5194/acp-10-6503-2010, 2010.

Ridley, B. A., Atlas, E. L., Montzka, D. D., Browell, E. V., Cantrell, C. A., Blake, D. R., Blake, N. J., Cinquini, L., Coffey, M. T., Cohen, R. C., DeYoung, R. J., Dibb, J. E., Eisle, F. L., Flocke, F. M., Fried, A., Grahek, F. E., Grant, W. B., Hair, J. W., Hannigan, J. W., Heikes, B. J., Lefer, B. L., Mauldin, R. L., Moody, J. L., Shetter, R. E., Snow, J. A., Talbot, R. W., Thornton, J. A., Walega, J. G., Weinheimer, A. J., Wert, B. P., and Wimmers, A. J.: Ozone depletion events observed in the high latitude surface layer during the TOPSE aircraft program, J. Geophys. Res., 108, 8356, doi:10.1029/2001JD001507, 2003.

Salawitch, R. J., Canty, T., Kurosu, T., Chance, K., Liang, Q., da Silva, A., Pawson, S., Nielsen, J. E., Rodriguez, J. M., Bhartia, P. K., Liu, X., Huey, L. G., Liao, J., Stickel, R. E., Tanner, D. J., Dibb, J. E., Simpson, W. R., Donohoue, D., Weinheimer, A., Flocke, F., Knapp, D., Montzka, D., Neuman, J. A., Nowak, J. B., Ryerson, T. B., Oltmans, S., Blake, D. R., Atlas, E. L., Kinnison, D. E., Tilmes, S., Pan, L. L., Hendrick, F., Van Roozendael, M., Kreher, K., Johnston, P. V., Gao, R. S., Bui, T. P., Chen, G., Pierce, R. B., Crawford, J. H., and Jacob, D. J.: A new interpretation of total column BrO during Arctic spring, Geophys. Res. Lett., 37, doi:10.1029/2010GL043798, 2010.

Scheuer, E., Talbot, R. W., Dibb, J. E., Seid, G. K., DeBell, L., and Lefer, B.: Seasonal distributions of fine aerosol sulfate in the North American Arctic basin during TOPSE, J. Geophys. Res., 108, 8370, doi:10/1029/2001JD001364, 2003.

Simpson, W. R., Alvarez-Aviles, L., Douglas, T. A., Sturm, M., and Domine, F.: Halogens in the coastal snow pack near Barrow, Alaska: Evidence for active bromine air-snow chemistry during springtime, Geophys. Res. Lett., 32, L04811, doi:10.1029/2004GL021748, 2005.

Simpson, W. R., von Glasow, R., Riedel, K., Anderson, P., Ariya, P., Bottenheim, J., Burrows, J., Carpenter, L. J., Frieß, U., Goodsite, M. E., Heard, D., Hutterli, M., Jacobi, H.-W., Kaleschke, L., Neff, B., Plane, J., Platt, U., Richter, A., Roscoe, H., Sander, R., Shepson, P., Sodeau, J., Steffen, A., Wagner, T., and Wolff, E.: Halogens and their role in polar boundary-layer ozone depletion, Atmos. Chem. Phys., 7, 4375-4418, doi:10.5194/acp-74375-2007, 2007.
Sjostedt, S. J., Huey, L. G., Tanner, D. J., Pieschl, J., Chen, G., Dibb, J. E., Lefer, B., Hutterli, M. A., Beyersdorf, A. J., Blake, N. J., Blake, D. R., Sueper, D., Ryerson, T., Burkhardt, J., and Stohl, A.: Observations of hydroxyl and the sum of peroxy radicals at Summit, Greenland during summer 2003, Atmos. Environ., 41, 5122-5137, doi:10.1016/j.atmosenv.2006.06.065, 2007.

Stutz, J., Oh, H.-J., Whitlow, S. I., Anderson, C., Dibb, J. E., Flynn, J. H., Rappengluck, B., and Lefer, B.: Simultaneous DOAS and mist-chamber IC measurements of HONO in Houston, TX, Atmos. Environ.,44, 4090-4098, doi:10.1016/j.atmosenv.2009.02.003, 2010a.

Stutz, J., Thomas, J. L., Hurlock, S. C., Schneider, M., von Glasow, R., Piot, M., Gorham, K., Burkhart, J. F., Ziemba, L., and Dibb, J.: Observations of $\mathrm{BrO}$ at Summit, Greenland, Atmos. Chem. Phys. Discuss., in preparation, 2010b.

Talbot, R. W., Vijgen, A. S., and Harriss, R. C.: Measuring tropospheric HNO3: Problems and prospects for nylon filter and mist chamber techniques, J. Geophys. Res., 95, 7553-7561, 1990.

Thomas, J., Toyota, K., Stutz, J., and von Glasow, R.: Modeling chemistry in and above snow at Summit, Greenland - Part 1: Model description and results, Atmos. Chem. Phys. Discuss., in preparation, 2010.

Toom-Sauntry, D. and Barrie, L. A.: Chemical composition of snow-fall in the high Arctic: 1990-1994, Atmos. Environ., 36, 2683-2693, 2002.

von Glasow, R. and Crutzen, P. J.: Tropospheric Halogen Chemistry, in: Treatise on Geochemistry Update 1, edited by: Holland, H. D. and Turekian, K. K., vol. 4.02, 1-67, 2007.

Yang, J., Honrath, R. E., Peterson, M. C., Dibb, J. E., Sumner, A. L., Shepson, P. B., Frey, M., Jacobi, H.-W., Swanson, A., and Blake, N.: Impacts of snowpack photochemistry on levels of $\mathrm{OH}$ and peroxy radicals at Summit, Greenland, Atmos. Environ., 36, 2523-2534, 2002.

Ziemba, L. D., Dibb, J. E., Griffin, R. J., Anderson, C. H., Whitlow, S. I., Lefer, B. L., Rappengluck, B., and Flynn, J.: Heterogeneous conversion of nitric acid to nitrous acid on the surface of primary organic aerosol in an urban atmosphere, Atmos. Environ., 44, 4081-4089, doi:10.1016/j.atmosenv.2009.12.024, 2010. 